\title{
In vitro effects of polyvalent immunoglobulin for intravenous use
}

\author{
I N van Schaik, $M$ Vermeulen, A Brand
}

High dose intravenous immunoglobulin (IVIg) therapy is used in the treatment of a wide range of auto-immune or presumed immune-mediated neurological disorders. A beneficial effect of IVIg has been reported in Guillain-Barré syndrome, ${ }^{1}$ chronic inflammatory demyelinating polyneuropathy, ${ }^{2-6}$ myasthenia gravis, ${ }^{78}$ multiple sclerosis, ${ }^{9}$ multifocal motor neuropathy, ${ }^{10-12}$ intractable childhood epilepsy, ${ }^{13}$ and dermato- and polymyositis. ${ }^{14} 15$

The mechanisms of response to IVIg treatment in these disorders is not fully understood. Firstly, adequate models to study the effects of IVIg are lacking. Secondly, treatment with IVIg has probably multiple effects on induction and amplification, as well as the effector phase of the immune response.

\section{Effects of IVIg on the effector phase of the immune response}

Most studies on IVIg have dealt with the effector phase of the immune response. It has been demonstrated that IVIg has the following effects in vivo: inhibition of autoantibody production, ${ }^{16}$ neutralisation of circulating pathogenic antibodies, ${ }^{17-21}$ and decrease of antibody dependent cellular cytotoxicity (ADCC) by Fc receptor blockade. ${ }^{22}$ In vitro it was shown that IVIg inhibits pokeweed mitogen stimulated antibody production, ${ }^{23-26}$ contains anti-idiotypic antibodies against multiple auto-antibodies, ${ }^{18-21}$ 27-29 suppresses ADCC, ${ }^{30-32}$ decreases natural killer cell function, ${ }^{33}$ and interferes with complement-activation. ${ }^{34} 35$ These mechanisms are dependent on the presence of the intact IgG molecule, which has a half-life of approximately three weeks in vivo. ${ }^{36}$ However, the observed long term effect of IVIg treatment, in some diseases for up to three months, is not fully explained by the modes of action already mentioned. IVIg may therefore modulate auto-immunity at other levels of the immune response.

\section{Effects of IVIg on the induction and amplification phase of the immune response}

ANTIPROLIFERATIVE EFFECTS

The effects of IVIg on the induction and amplification of the immune response in which the $\mathrm{CD}^{+}$helper $\mathrm{T}$-cell interacts with antigen presenting cells (in a way that costimulatory signals are activated) has not yet been explored. Interactions of IVIg with $\mathrm{T}$-cells have been scarcely investigated. ${ }^{37}$ An enhancement of CD8 positive suppressor Tcell function in vivo has been reported..$^{38-40}$ Furthermore, IVIg appears to interfere with the cytokine network. In vitro administration of IVIg results in induction of the interleukin1 receptor antagonist and downregulation of the production of Il-1 and tumour necrosis factor- $\alpha$. Moreover, antibodies against Il-1 $\alpha$ have been demonstrated in IVIg. ${ }^{41-43}$

We recently showed inhibitory effects of IVIg on antigen-specific and non-specific stimulated lymphocytes. ${ }^{44}$ Subsequent experiments showed that IVIg added to cultures of various autonomously growing cell lines (including the haematopoietic cells HL-60, Daudi, Molt-4 and K562, B-cell hybridomas, EBV transformed B-cells and neuroblastoma cell lines of various human and non-human origin) also ceased with proliferation. We demonstrated that IVIg interfered with DNAsynthesis and protein metabolism. ${ }^{3} \mathrm{H}$-thymidine uptake of activated cells was measured, after incubation with IVIg for various intervals. IVIg interferes with ${ }^{3} \mathrm{H}$-thymidine uptake, in a dose-dependent fashion, regardless of the stimulus. To confirm these observations, cells cultured with and without IVIg, were pulse-labelled with bromodeoxyuridine (BrdU) and subsequently analysed in an immunofluorescence-assay. The BrdU labelling studies showed that cells were arrested in the $G_{0}-G_{1}$ - and no longer progressed into the S-phase. Similar results were obtained with normal human myoblasts and fibroblasts in culture. Parallel experiments with similar concentrations of human albumin did not show these effects. There was no apparent cytotoxic effect, as removal of IVIg within an interval of several days and reculturing in fresh medium, resulted in normal proliferation of $\mathrm{K} 562$, HL-60, EBV transformed B-cells, human myoblast and fibroblast. Further experiments are needed to exclude that a proportion of cells are induced to apoptosis.

\section{GROWTH FACTOR SIGNALLING}

A possible explanation for this broad proliferative arrest could be the interference of IVIg with essential growth factors. Il-1 $a$, Il-2, Il-3 
Putative effects of IVIg on induction, amplification and effector phase of the immune response.

Induction and activation phase

Effect on signal transduction

Inhibitory effect on antigen-specific stimulated lymphocytes*

Inhibitory effect on antigen non-specific stimulated

lymphocytes (PHA, PWM)

Enhancement of CD8 positive suppressor $T$-cell function ${ }^{\star}$

CD4 helper T-cell activation

Amplification phase

Effect on co-stimulatory cells

Effect on accessory cells

Interference with the cytokine network ${ }^{\star}$

Proliferation and maturation phase

Interference with growth factors (receptors and production)

Interference with DNA synthesis *

Interference with protein metabolism

Interference with antibody production*

Effector phase

Binding to Fc $\gamma \mathrm{I}, \mathrm{II}, \mathrm{III}$ receptors*

Neutralisation of circulating pathogenic antibodies*

Anti-idiotypic interactions

Decrease of ADCC by Fc $\gamma$ receptor blockade ${ }^{\star}$

Decrease of natural killer cell function*

Interference with complement activation *

$\star$ published effects of IVIg, see text

and supernatant of lymphokine (CD3 and Il2) activated killer cells were therefore added in increasing doses to lymphocytes in various antigen specific and antigen non-specific stimulated models, as well as to various autonomously growing cell-lines. However, this could not abolish the inhibitory effect of IVIg. These results suggest that these interleukins do not interact with IVIg.

There are many similarities between IVIg and tumour growth factor- $\beta$. TGF- $\beta$ has inhibitory effects on various T-cell and B-cell interactions and activities, on tumour cells and normal cell proliferation. ${ }^{45} 46$ To exclude the possibility that IVIg contains TGF- $\beta$ activity we added anti-TGF- $\beta$ neutralising antibody to IVIg. Despite increasing doses of this antibody we found no reduction of the anti-proliferative effect of IVIg.

Fc $\gamma$-RECEPTOR SIGNALIING

Another explanation for the anti-proliferative action of IVIg could be the binding to a receptor providing essential cofactors for growth of activated or autonomous proliferating cells. Fc $\gamma$-receptors might be the common denominator between the various cell types affected by IVIg. The expression of the distinct Fcy-receptors was measured in an immunofluorescence assay using monoclonal antibodies against CD64 (Fc $\gamma \mathrm{RI}), \mathrm{CD} 32$ (Fc $\gamma$ RII), and CD16 (Fc $\gamma$ RIII). ${ }^{47}$ However, most cells are lacking Fc $\gamma$ I, II, and III receptor expression. IVIg contains multiple antibodies against polymorphic (HLA class I or II) and non-polymorphic (CD5 receptor) structures. ${ }^{489}$ Binding of IVIg to HLA antigens is an unlikely explanation for this effect as some cell lines which were inhibited in a dose-dependent fashion by IVIg, for instance the Daudi cell-line, do not express HLA antigens on their surface.

\section{Conclusion}

Our results show that, in addition to the $\mathrm{F}(\mathrm{ab})_{2}$-mediated anti-idiotypic neutralisation of autoantibodies, the Fc-mediated immunoregulation of $\mathrm{B}$-cell function and the depression of monocyte effector ADCC-function, IVIg interferes with cell proliferation in vitro and reversibly arrests growth of various cell populations. By which mechanism(s) this inhibitory effect of IVIg on cell proliferation is mediated is currently under study. Besides the interference on the effector phase of the immune response, IVIg profoundly modulates in vitro the induction and probably the amplification phase of the immune response.

1 Van der Meché FGA, Schmitz PIM, The Dutch GuillainBarré Study Group. A randomized trial comparing intravenous immune globulin and plasma exchange in Guillain-Barré syndrome. $N$ Engl $f$ Med 1992;326: 1123-9.

2 Van Doorn PA, Vermeulen M, Brand A, Mulder PGH, Busch HFM. Intravenous immunoglobulin treatment in patients with chronic inflammatory demyelinating polyneuropathy. Arch Neurol 1991;48:217-20.

3 Cornblath DR, Chaudhry V, Griffin JW. Treatment of chronic inflammatory demyelinating polyneuropathy with intravenous immunoglobulin. Ann Neurol 1991;30: 104-6.

4 Vermeulen $M$, Van der Meché FGA, Speelman JD, Weber A, Busch HFM. Plasma and gamma-globulin infusion in chronic inflammatory polyneuropathy. $f$ infusion in chronic inflam

5 Van Doorn PA, Brand A, Strengers PFW, Meulstee J, Vermeulen $M$. High-dose intravenous immunoglobulin treatment in chronic inflammatory demyelinating polyneuropathy: a double-blind, placebo-controlled, crossover study. Neurology 1990;40:209-12.

6 Vermeulen M, Van Doorn PA, Brand A, Strengers PFW, Jennekens FGI, Busch HFM. Intravenous immunoglobulin treatment in patients with chronic inflammatory demyelinating polyneuropathy. $\mathcal{f}$ Neurol Neurosurg Psychiatry 1993;56:36-9.

7 Arsura E. Experience with intravenous immunoglobulin in myasthenia gravis. Clin Immunol Immunopathol 1989;53: S170-9.

8 Cook L, Howard JF, Folds JD. Immediate effects of intravenous IgG administration on peripheral blood $B$ and $T$ cells and polymorphonuclear cells in patients with myasthenia gravis. F Clin Immunol 1988;8:23-31.

9 Schuller E, Govaerts A. First results of immunotherapy with immunoglobulin $\mathrm{G}$ in multiple sclerosis patients. Eur Neurol 1993;22:205-12.

10 Kaji R, Shibasaki H, Kimura J. Multifocal demyelinating motor neuropathy: cranial nerve involvement and immunoglobulin therapy. Neurology 1992;42:506-9.

11 Chaudhry V, Corse AM, Cornblath DR, et al. Multifocal motor neuropathy: response to human immune globumotor neuropathy: response to
lin. Ann Neurol 1993;33:237-42.

12 Nobile-Orazio E, Meucci N, Barbieri S, Carpo M, Scarlato G. High-dose intravenous immunoglobulin therapy in multifocal motor neuropathy. Neurology 1993;43:537-44.

13 Illum N, Tandorf $\mathrm{K}$, Heilmann $\mathrm{C}$, et al. Intravenous immunoglobulin: a single-blind trial in children with Lennox-Gastaut syndrome. Neuropediatrics 1990;21: 87-90.

14 Lang BA, Laxer RM, Murphy G, Silverman ED, Roifman CM. Treatment of dermatomyositis with intravenous gammaglobulin. Am f Med 1991;91:169-72.

15 Cherin P, Herson S, Wechsler B. Efficacy of intravenous gammaglobulin therapy in chronic refractory polymyositis and dermatomyositis: an open study with 20 adult patients. Am f Med 1991;91:162-8.

16 Jayne DRW, Davies MJ, Fox CJV, Black CM, Lockwood CM. Treatment of systemic vasculitis with pooled intraCM. Treatment of systemic vasculitis with pooled
venous immunoglobulin. Lancet 1991;337:1137-9.

17 Sultan Y, Kazatchkine MD, Nydegger U, Rossi F, Dietrich $G$, Algiman $M$. Intravenous Immunoglobulin in the treatment of spontaneously acquired factor VIII:C inhibitors. Am $\mathcal{F}$ Med 1991;91:5A-35S-39S.

18 Sultan Y, Rossi F, Kazatchkine MD. Recovery from antiVIII:C (antihemophilic factor) autoimmune disease is dependent on generation of antiidiotypes against antiVIII:C autoantibodies. P Natl Acad Sci USA 1987; 84:828-31.

19 McGuire W, Yang HH, Bruno E, et al. Treatment of antibody-mediated pure red-cell aplasia with high-dose intravenous gamma globulin. $N$ Engl $f$ Med 1987; 317:1004-8.

20 Brand A, Witvliet M, Claas FHJ, Eernisse JG. Beneficial effect of intravenous gammaglobulin in a patient with complement-mediated autoimmune trombocytopenia complement-mediated autoimmune trombocytopenia due to IgM-ant $1988 ; 70: 1-5$.

21 Lundkvist I Van Doorn PA, Vermeulen $M$, Van Lint $M$, Van Rood JJ, Brand A. Regulation of autoantibodies in inflammatory demyelinating polyneuropathy: spontaneous and therapeutic. Immunol Rev 1989;110:105-17. 
22 Fehr J, Hofmann V, Kappeler U. Transient reversal of thrombocytopenia in idiopathic trombocytopenic purthrombocytopenia in idiopathic trombocytopenic purpura by high-dose intraven
$¥ \mathrm{Med} 1982 ; 306: 1254-8$

23 Hashimoto F, Sakiyama Y, Matsumoto S. The suppressive effect of gammaglobulin preparations on in vitro pokeweed mitogen-induced immunoglobulin production. Clin Exp Immunol 1986;65:409-15.

24 Stohl $W$. Cellular mechanisms in the in vitro inhibition of pokeweed mitogen-induced $B$ cell differentiation by immunoglobulin for intravenous use. F Immunol 1986; 136:4407-13.

25 Kondo N, Ozawa T, Mushiake K, et al. Suppression of immunoglobulin production of lymphocytes by intravenous immunoglobulin. $f$ Clin Immunol 1991;11: 152-8.

26 Tsubakio T, Kurata Y, Katagiri S, et al. Alteration of T cell subsets and immunoglobulin synthesis in vitro during high dose gamma-globulin therapy in patients with ing high dose gamma-globulin therapy in patients with idiopathic thromb

27 Rossi F, Kazatchkine MD. Antiidiotypes against autoantibodies in pooled normal human polyspecific Ig. $\mathcal{F}$ Immunol 1989;143:4104-9.

28 Lundkvist I, Van Doorn PA, Vermeulen M, Brand A. Spontaneous recovery from the Guillain-Barré syndrome is associated with anti-idiotypic antibodies recognizing a cross-reactive idiotype on anti-neuroblastoma cell line antibodies. Clin Immunol Immunopathol 1993; 67:192-8.

29 Dietrich G, Pereira P, Algiman M, Sultan Y, Kazatchkine MD. A monoclonal anti-idiotypic antibody against the Mn. A monoclonal anti-idiotypic antibody against the ies defines an idiotope that is recognized by normal ies defines an idiotope that is recognized by normal human polyspecific immunoglobulins for
use (IVIg). ₹ Autoimmun 1990;3:547-57.

30 Jungi TW, Santer M, Lerch PG, Barandun S. Effect of various treatments of gamma-globulin (IgG) for achieving intravenous tolerance on the capacity to interact with human monocyte Fc receptors. Vox Sang 1986; 51:18-26.

31 Kurlander RJ. Reversible and irreversible loss of Fc receptor function of human monocytes as a consequence of interaction with immunoglobulin G. $\mathcal{f}$ Clin Invest 1980; 66:773-81.

32 Saleh $M$, Court W, Huster W, Shaw D, Lobuglio A Effect of commercial immunoglobulin $G$ preparation on human monocyte Fc-receptor dependent binding of antibody coated platelets. Brit $\mathcal{f}$ Haematol 1988;68: antibody

33 Engelhard D, Waner JL, Kapoor N, Good RA. Effect of intravenous immune globulin on natural killer cell activity: possible association with autoimmune neutropenia and idiopathic trombocytopenia. $F$ Pediatr 1986;108: 77-81.

34 Frank MM, Basta M, Fries LF. The effects of intravenous immune globulin on complement-dependent immune damage of cells and tissues. Clin Immunol Immunopathol 1992;62:S82-S86.
35 Basta M, Kirshbom P, Frank MM, Fries LF. Mechanism of therapeutic effect of high-dose intravenous immunoglobulin; Attenuation of acute, complementdependent immune damage in a guinea pig model. $f$ Clin Invest 1989;84:1974-81.

36 Kaveri SV, Dietrich G, Hurez V, Kazatchkine MD. Intravenous immunoglobulin (IVIg) in the treatment of Intravenous immunoglobulin (IVIg) in the treatment of

37 Kawada K, Terasaki PI. Evidence for immunosuppression by high-dose gammaglobulin. Exp Hematol 1987;15 133-6.

38 Delfraissy JF, Tchernia G, Laurian Y, Wallon C, Galanaud P, Dormont J. Suppressor cell function after intravenous gammaglobulin treatment in adult chronic idiopathic thrombocytopenic purpura. Brit $f$ Haemato 1985;60:315-22.

39 Macey MG, Newland AC. CD4 and CD8 subpopulation changes during high dose intravenous immunoglobulin treatment. Brit $f$ Haematol 1990;76:513-20.

40 Leung DYM, Burns JC, Newburger JW, Geha RS. Reversal of lymphocyte activation in vivo in the Keversal of lymphocyte activation in vivo in the Kawasaki syndrome by intra

41 Schifferli JA, Didierjean L, Saurat JH. Immunomodulatory effects of intravenous immunoglobulin $\mathrm{G}$. $\mathcal{f}$ Rheumatol 1991;18:937-9.

42 Arend WP, Smith MF, Janson RW, Joslin FG. IL-1 receptor antagonist and $\mathrm{IL-1}$ beta production in human monocytes are regulated differently. F Immunol 1991; 147:1530-5.

43 Shimozato $T$, Iwata $M$, Kawada $H$, Tamura $N$. Human immunoglobulin preparation for intravenous use induces elevation of cellular cyclic adenosine $3^{\prime}: 5^{\prime}$ monophosphate levels, resulting in suppression of monophosphate levels, resulting in suppression of tumour necrosis factor alpha and inte

44 Van Schaik IN, Lundkvist I, Vermeulen $M$, Brand A Polyvalent immunoglobulin for intravenous use interferes with cell proliferation in vitro. $f$ Clin Immunol 1992;12:1-10.

45 Bartlett WC, Purchio A, Fell HP, Noelle RJ. Cognate interactions between helper $T$ cells and $B$ cells. VI. TGF- $\beta$ inhibits $B$ cell activation and antigen-specific, physical interactions between $T_{h}$ and $B$ cells. Lymphokine Cytokine Res 1991;10:177-83.

$46 \mathrm{Kehrl}$ JH, Taylor A, Kim S-J, Fauci AS. Transforming growth factor- $\beta$ is a potent negative regulator of human lymphocytes. Ann NY Acad Sci 1991;628: human

47 Ravetch JV, Kinet J-P. Fc receptors. Annu Rev Immunol 1991;9:457-92.

48 Overweg J, Engelfriet CP. Cytotoxic leucocyte isoantibodies formed during the first pregnancy. Vox Sang 1969;16:97-104.

49 Vassilev T, Gelin C, Kaveri SV, Zilber MT, Boumsell L Kazatchkine MD. Antibodies to the CD5 molecule in normal human immunoglobulins for therapeutic use (intravenous immunoglobulins, IVIg). Clin Exp Immuno 1993;92:369-72. 